\title{
Numerical Simulations of Seasonal Variations of Rainfall over the Island of Hawaii
}

\author{
Yu-Fen HuANG AND Yi-Leng CHEN \\ Department of Atmospheric Sciences, University of Hawai'i at Manoa, Honolulu, Hawaii
}

(Manuscript received 15 March 2018, in final form 28 February 2019)

\begin{abstract}
The seasonal variations of rainfall over the island of Hawaii are studied using the archives of the daily model run from the fifth-generation Pennsylvania State University-NCAR Mesoscale Model (MM5) from June 2004 to February 2010. Local effects mainly drive the rainfall on the Kona coast in the early morning and the lower slopes in the afternoon. During the summer, the incoming trade winds are more persistent and moister than in winter. The moisture content in the wake zone is higher than open-ocean values because of the convergent airflow associated with dual counterrotating vortices. As the westerly reversed flow moves toward the Kona coast, it decelerates with increasing moisture and a moisture maximum over the coastal area, especially in the afternoon hours in summer months. The higher afternoon rainfall on the Kona lower slopes in summer than in winter is caused by a moister $(>6 \mathrm{~mm})$ westerly reversed flow bringing moisture inland and merging with a stronger upslope flow resulting from solar heating. Higher nocturnal rainfall off the Kona coast in summer than in winter is caused by the low-level convergence between a moister westerly reversed flow and offshore flow. On the windward slopes, the simulated rainfall accumulation in winter is higher because of frequently occurring synoptic disturbances during the winter storm season. Nevertheless, early morning rainfall along the windward coast and afternoon rainfall over the windward slopes of the Kohala Mountains is lower in winter because the incoming trades are drier.
\end{abstract}

\section{Introduction}

In the Hawaiian Islands, northeasterly trade winds of $5-10 \mathrm{~m} \mathrm{~s}^{-1}$ are persistent throughout the year, with the maximum trade wind occurrence reaching $92 \%$ in August (Schroeder 1993). The island of Hawaii, hereinafter the "Big Island," is the largest and southeastern-most island of the Hawaiian Island chain. It has a land area of $10430 \mathrm{~km}^{2}$ with two massive volcanoes, Mauna Loa and Mauna Kea, with peaks $>4000 \mathrm{~m}$. The trade wind inversion (TWI) ( $\sim 1900 \mathrm{~m}$ above the mean sea level) (Winning et al. 2017) serves as a "lid" that prevents the low-level flow from moving above the TWI (Leopold 1949; Chen and Feng 1995; Giambelluca and Schroeder 1998). The maximum rainfall areas correspond to regions with persistent orographic lifting on the windward side, with low rainfall in the leeward areas, and atop high mountains with tops above the TWI (Giambelluca et al. 1986, 2013).

For a stratified flow past an isolated mountain barrier, the Froude number $[\mathrm{Fr}=U /(\mathrm{Nh})$, where $U$ is the upstream wind speed, $N$ is the Brunt-Väisälä frequency, and $h$ is the height of the barrier] is a control flow parameter

Corresponding author: Dr. Yi-Leng Chen, yileng@hawaii.edu
(Smolarkiewicz et al. 1988; Rasmussen and Smolarkiewicz 1993). For typical trade wind conditions in Hawaii, Fr is about 0.3 and the incoming low-level flow decelerates and is deflected by the orographically induced high pressure on the windward side. In addition to orographic blocking and TWI, the island-scale airflow and weather over the Big Island are modulated by thermally forced diurnal flows (Leopold 1949; Garrett 1980; Takahashi 1977; Chen and Nash 1994). In winter months (November-April), the island-scale airflow and weather are also affected by the synoptic conditions (Blumenstock and Price 1967; Meisner 1976; Kodama and Barnes 1997; Zhang et al. 2005a,b).

There are seasonal variations in rainfall over the Hawaiian Islands. Most areas exhibit a winter rainfall maximum. Nevertheless, the Kona leeside area on the Big Island has a pronounced summer rainfall maximum (Meisner 1976; Giambelluca et al. 1986, 2013; Kidd and McGregor 2007) with higher cloud frequencies (Barnes et al. 2016). Schroeder et al. (1977) and Giambelluca et al. (1986) attributed the rainfall on the lower Kona slopes to the thermally driven upslope flow in the afternoon hours in response to solar heating. The effect of seasonal variations in orographic blocking (Smolarkiewicz et al. 1988) and interactions between orographic blocking and diurnally 
driven winds (Chen and Nash 1994) on the production of Kona rainfall has not been investigated. Furthermore, the seasonal variations in mesoscale airflow and weather conditions off the Kona coast are not available from routine observations.

Chen and Nash (1994) and Yang and Chen (2003) suggested that the lifting of the westerly reversed flow by nighttime land breezes causes the coastal rainfall in the Kona area. Nevertheless, none of previous studies addressed the seasonal variations in airflow and weather conditions off the Kona coast and the impacts of these differences (summer versus winter) on the localized Kona leeside rainfall. In this study, the 6-yr archive (2004 to 2010) of daily high-resolution data from the fifth-generation Pennsylvania State University-National Center for Atmospheric Research Mesoscale Model (MM5, version 3.6.3) coupled with the NOAA/National Centers for Environmental Prediction (NCEP)-Oregon State University-Air Force Research Laboratory-NOAA/Office of Hydrology (Noah) land surface model (LSM) (Chen and Dudhia 2001; Ek et al. 2003) will be used to answer the following questions. 1) What are the differences in Kona leeside rainfall between summer dry season and winter storm season? What about the windward side? 2) What are the climatically annual (summer dry season vs winter storm season) and diurnal characteristics of the Kona rainfall? 3) What factors impact the Kona trade wind rainfall the most, including airflow and weather conditions off the Kona coast?

An overview of the island-scale airflow and weather is given in section 2. The data and methods used in this study will be described in section 3 . The island-scale microclimate under summer trade wind conditions constructed from the 6-yr archive of our once-daily model run will be given in section 4 . The winter microscale climate under trade wind conditions will be compared to the summer season, with particular attention to the Kona leeside rainfall (section 5). Winter trade winds are frequently interrupted by synoptic disturbances (Blumenstock and Price 1967; Kodama and Businger 1998; Zhang et al. 2005c; Tu and Chen 2011; and others). The microscale climate under all days in winter will be constructed and compared with winter trade wind days (section 6). We also discuss the reasons for the localized summer rainfall maxima in the Kona leeside area.

\section{An overview of island-scale airflow and weather under summer trade wind conditions over the Big Island}

The diurnal rainfall occurrences over the Big Island are related to interactions among orographic lifting, thermally driven diurnal winds, and dynamic blocking (Chen and Nash 1994). On the windward side, the rainfall frequency maximum along the windward coast shifts inland from the early morning (Takahashi 1977) to early evening (Schroeder et al. 1977; Chen and Nash 1994). In the afternoon, with solar heating, the maximum rainfall frequency occurs on the windward slopes because the upslope trade winds reinforce the orographic lifting (Garrett 1980; Chen and Nash 1994). After the onset of katabatic flow in the later afternoon/ early evening, trade wind showers occur most frequently over the windward lowlands because of the convergence between the katabatic flow and incoming trades (Chen and Nash 1994). Throughout the night, the katabatic winds are strengthened by combined nocturnal and rain evaporative cooling with the maximum offshore extent in the early morning $(20-50 \mathrm{~km})$ (Feng and Chen 1998, 2001; Wang and Chen 1998; Carbone et al. 1995). Under trade wind conditions, trade wind cumuli/showers embedded in the incoming flow could drift with the trade wind flow and enhanced by the island-induced flow as they move onshore (Austin et al. 1996; Wang and Chen 1998; Li and Chen 1999; Carbone et al. 1995, 1998; Frye and Chen 2001; and others).

In addition to the diurnal heating cycle, rainfall amounts and patterns on the windward side are also related to the strength of the trade wind flow and the TWI height (Chen and Feng 1995; Esteban and Chen 2008). When trades are stronger, the daily rainfall totals on the windward side are higher with a pronounced nocturnal maximum farther inland than under weak trades (Esteban and Chen 2008). When trades are weaker, the rainfall distribution has a late afternoon maximum on the windward slopes in response to solar heating. Furthermore, when the TWI height is higher, the afternoon daily rainfall totals on the windward slopes are greater than on days when the inversion is lower (Chen and Feng 1995, 2001).

Because of orographic blocking (Smolarkiewicz et al. 1988; Smolarkiewicz and Rotunno 1989; Rasmussen and Smolarkiewicz 1993; Smith and Grubišić 1993; Schär and Smith 1993; and others), the trade winds are absent from the Kona area behind the high mountains. The airflow on the Kona slopes is dominated by the thermally driven diurnal winds (Chen and Nash 1994; Yang et al. 2005). The daytime upslope flow produces convective rainfall on the slopes during the afternoon and early evening (Leopold 1949; Schroeder et al. 1977; Chen and Nash 1994). The northwestern and southwestern areas behind the ridge or saddle with tops below the TWI are semiarid with warm, dry conditions because of the adiabatic descent of trade wind flows aloft, especially under strong trade wind conditions (Chen and Nash 1994; Yang and Chen 2003). Afternoon showers can occur on the northwestern leeside area because of the convergence of the descending airflow from the Waimea Saddle and sea 
breezes, especially under weak trade wind conditions (Schroeder 1981; Chen and Nash 1994; Yang and Chen 2003; Zhang et al. 2005c).

The climatological airflow pattern over the ocean offshore the leeside coast was first reported from 15-yr ship observations (Patzert 1969). The existence of lee vortices was first documented from an analysis of aircraft flight-level data collected in the summer of 1980 (Nickerson and Dias 1981). The large wake adjacent to the Kona coast consists of two counterrotating vortices with a westerly reversed flow along the wake axis (Nickerson and Dias 1981; Smith and Grubišić 1993; Schär and Smith 1993). The water vapor content has a maximum along the axis of the westerly reversed flow because of the low-level convergence between the two counterrotating vortices (Yang and Chen 2003). The evening Kona rainfall maximum along the coast is caused by the convergence between the moist westerly reversed flow and the offshore flow (Chen and Nash 1994; Yang and Chen 2003).

Simulations of airflow and island weather over the Big Island were conducted to improve our basic understanding of the diurnal circulations and island effects. Feng and Chen (2001) simulated the nocturnal regime on the windward side of the Big Island using MM5. They initialized the model with a typical trade wind sounding constructed from the aircraft flight-level data collected upstream of the Big Island during the Hawaiian Rainband Project (HaRP). In the past, the sea-breeze circulation for northwest Hawaii and the summer trade wind weather over Oahu were simulated by a mesoscale spectral model (Juang et al. 2005) coupled with the advanced Noah LSM (Ek et al. 2003) using high-resolution land surface parameters (Zhang et al. 2005a,c). Yang et al. (2005) successfully simulated the island-scale circulation and weather over the Big Island throughout the entire diurnal cycle during HaRP for the first time using MM5/LSM (with 3-km grid) and improved surface parameters compiled by Zhang et al. (2005b). The simulation from Yang et al. (2005) confirmed that the nocturnal Kona leeside rainfall along the coast is caused by the low-level convergence between the westerly reversed flow and the offshore flow at night. Furthermore, the evening rainfall maximum along the Kona coast is higher under stronger trades $\left(\sim 7.9 \mathrm{~m} \mathrm{~s}^{-1}\right)$ because the low-level convergence is more significant (Yang and Chen 2003; Yang and Chen 2008).

\section{Data and methods}

\section{a. The simulation}

MM5 (version 3.6.3) is a three-dimensional primitive equation model with a terrain-following sigma vertical coordinate. The archive of daily high-resolution (grid size $3 \mathrm{~km}$ ) MM5 output during June 2004-February 2010 is used for this study. The model configuration is identical to that given by Yang et al. (2005). Results from the $3-\mathrm{km}$ model for the island of Hawaii have been validated by HaRP observations including data from 50 Portable Automatic Mesonet (PAM) surface stations, Hilo (Hawaii) soundings, and aircraft flight-level data (Yang et al. 2005).

The advanced Noah LSM is employed with soil moisture and temperature using four layers with depths of 10, 40,100, and $200 \mathrm{~cm}$ (Chen and Dudhia 2001). The updated land use, soil type, and vegetation cover for the Big Island were compiled by Zhang et al. (2005c). The daily high-resolution MM5/LSM experimental simulations used soil moisture and soil temperature updated from the 24-h forecast of the previous day. The similarity theory is used for profiles in the surface layer. The daily 36-h MM5 runs were initialized by the NCEP Global Forecast System (GFS) data at 0000 UTC and the sea surface temperature (SST) is from the NCEP SST analysis. The simulated diurnal cycles are represented by the model daily output during the 12th-35th hour simulation. Four nested domains with two-way nesting are employed with horizontal grid sizes of 81,27, 9, and $3 \mathrm{~km}$ (Fig. 1a), respectively. There are 29 sigma levels from the surface to the 100-hPa level. Grell's cumulus parameterization (Grell 1993), an explicit gridscale warm rain microphysics (Hsie et al. 1984), a cloud radiation scheme (Dudhia 1989), and the medium-range forecast (MRF) planetary boundary layer scheme (Hong and Pan 1996) are used in the model. The cumulus parameterization scheme is not used for the $3-\mathrm{km}$ Big Island domain. Trade wind showers (Takahashi et al. 1989; Takahashi 1977) and torrential rainstorms in Hawaii (e.g., Cram and Tatum 1979) are frequently dominated by a warm rain process. For the state of Hawaii, most of the weather-related threat to life and property during the winter storm season is from heavy rains and attendant flash flooding (Kodama and Barnes 1997; Tu and Chen 2011; Jayawardena et al. 2012; and others); lightning strikes and hail storms are relatively rare (Kodama and Businger 1998; Blumenstock and Price 1967). Hailstones in Hawaii contain many supercooled droplets, which suggest that hail-producing storms may have a high concentration of supercooled water (Takahashi 1987). Weak convective-scale updrafts in oceanic convection in the subtropics (Jorgensen and LeMone 1989) as well as the warm temperatures of the lower troposphere are likely the main factors for the rare occurrence of hail in Hawaii (Kodama and Businger 1998). Nevertheless, application of explicit warm rain process in the model may underestimate rainfall accumulation, especially during the winter storm season. 

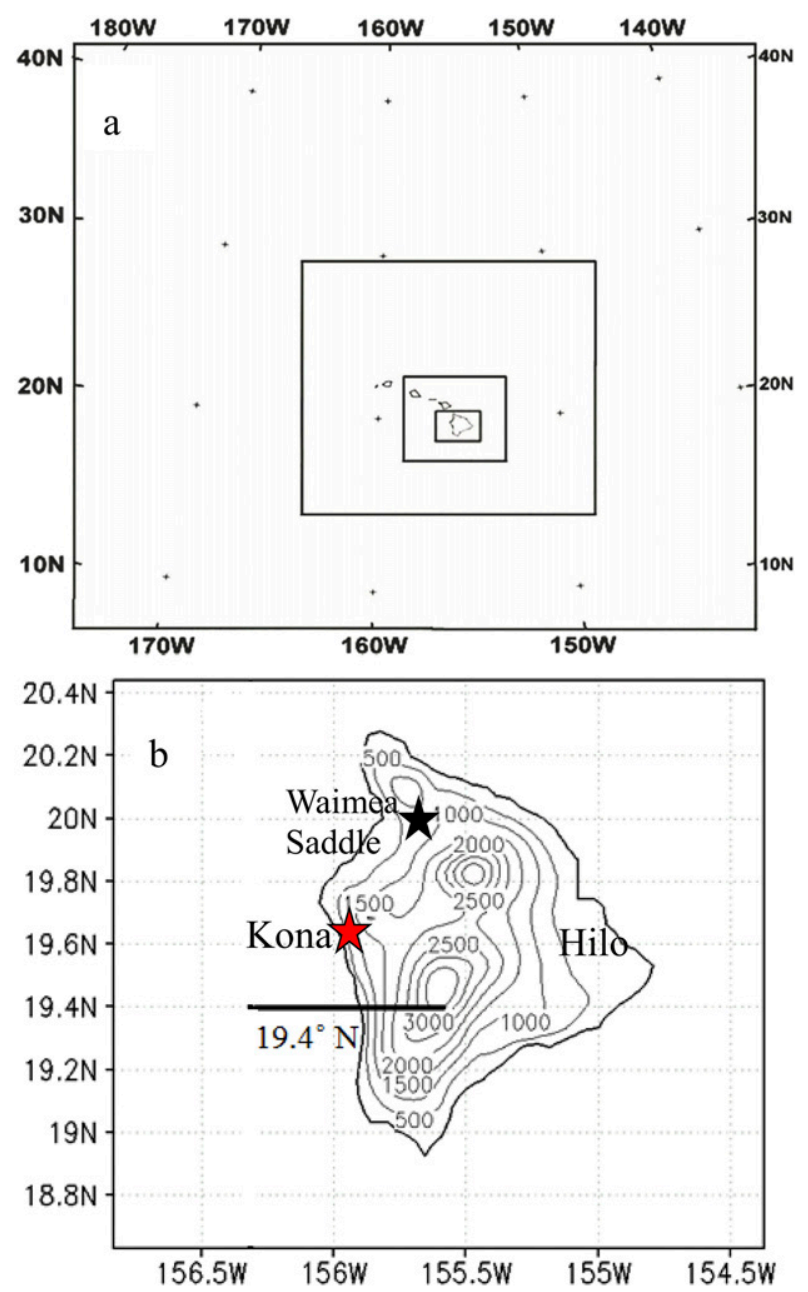

FIG. 1. (a) The four nested domains with horizontal grid sizes of 81, 27, 9, and $3 \mathrm{~km}$ [after Yang and Chen (2008)]. (b) The Big Island with model terrain height every $500 \mathrm{~m}$. The thick solid line shows the locations of vertical cross sections used in the analyses along $19.4^{\circ} \mathrm{N}$ (from $156.3^{\circ}$ to $155.5^{\circ} \mathrm{W}$ ); the red star is Kailua-Kona, and the black star is Waimea Saddle.

A similar modeling strategy was applied to the islands of Oahu (Nguyen et al. 2010) and Maui (Carlis et al. 2010) with a horizontal grid size of 1.5 and $2 \mathrm{~km}$, respectively. Results from both studies are validated against data collected from rain gauges and surface stations. Simulated monthly summer rainfall over Oahu is also compared with radar-derived rainfall (Nguyen et al. 2010). Despite Oahu's relatively small area $\left(1536 \mathrm{~km}^{2}\right)$, there are considerable spatial variations in the horizontal distribution of thermodynamic fields, airflow and rainfall during the diurnal heating cycle, which are well simulated by the high-resolution model with a grid size of $1.5 \mathrm{~km}$ (Nguyen et al. 2010). The simulated rainfall over the Ko'olau Mountains exhibits an afternoon minimum. The westerly reversed flow off the western leeside coast in the afternoon is related to land surface heating superimposed by latent heat release of persistent orographic precipitation over the Ko'olau Mountains. Rainfall along the western leeside slopes is infrequent and mainly occurs in late afternoon hours as light showers because of the development of the onshore/upslope flow. These results are in agreement with Hartley and Chen (2010). From the results of the 2-km simulations, Carlis et al. (2010) show that the previously known closed circulation over the Central Valley of Maui, or the Maui vortex, represents the northern cyclonic vortex of the dual-counter-rotating vortices in the lee of Haleakala with a westerly reversed flow $\left(\sim 2 \mathrm{~m} \mathrm{~s}^{-1}\right)$ extending up to the base of the trade wind inversion. The northern cyclonic vortex is more pronounced than the southern anticyclonic vortex because of the shape of Haleakala and the flow deflection of the incoming flow by the western Maui Mountains. The westerly reversed flow and the Maui vortex are simulated throughout the diurnal heating cycle, except near the surface. The leeside slope surface is dominated by daytime upslope/anabatic flow and nighttime katabatic flow.

\section{b. The trade wind days}

During the winter months, there are periods with nontrade wind days when light and variable winds may occur with suppressed conditions and clear skies (Barnes et al. 2016) when the ridge axis of the subtropical high is close to the Hawaiian Island chain. Furthermore, the trade wind flow is frequently interrupted by synoptic disturbances, e.g., cold fronts, upperlevel troughs, and Kona storms during the winter months and occasionally by tropical storms during the summer (Blumenstock and Price 1967). By considering trade wind days only, the high-resolution model results allow us to assess the impact of environmental conditions on island-scale circulations and weather under trade wind conditions. The trade wind days are selected by using the NCEP/FNL reanalysis data and the following criteria: 1 ) wind direction is between $45^{\circ}$ and $100^{\circ}$ with wind speed between 3 and $10 \mathrm{~m} \mathrm{~s}^{-1}$ on the open ocean of the northeastern Hawaiian Islands at the surface; 2) no tropical cyclone, Kona low, cold front, or upper-level trough at the $250-\mathrm{hPa}$ level within $170^{\circ}-$ $145^{\circ} \mathrm{W}$ and $12^{\circ}-28^{\circ} \mathrm{N}$; and 3) no postfrontal days with strong $\left(>10 \mathrm{~m} \mathrm{~s}^{-1}\right)$ easterly winds (Zhang et al. 2005a). The occurrences of trade wind days from June 2004 to February 2010 are $77 \%$ in the summer months (June, July, and August) and $26.1 \%$ in the winter months (December, January, and February), respectively.

The overall pattern of simulated mean daily rainfall accumulation during summer (Fig. 2a) resembles the accumulated rainfall during HaRP (Chen and Nash 1994; 


\section{a) summer}

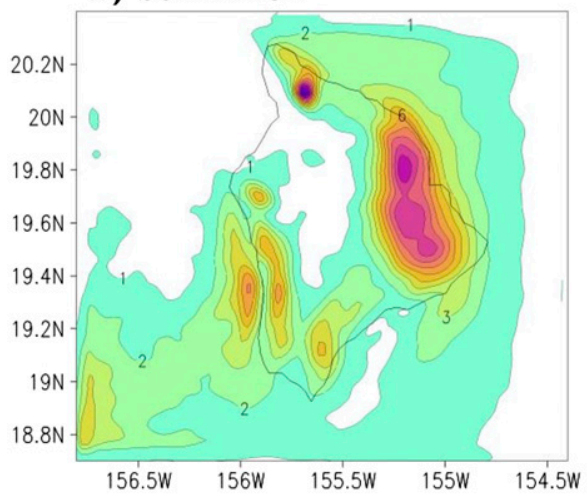

c) summer median

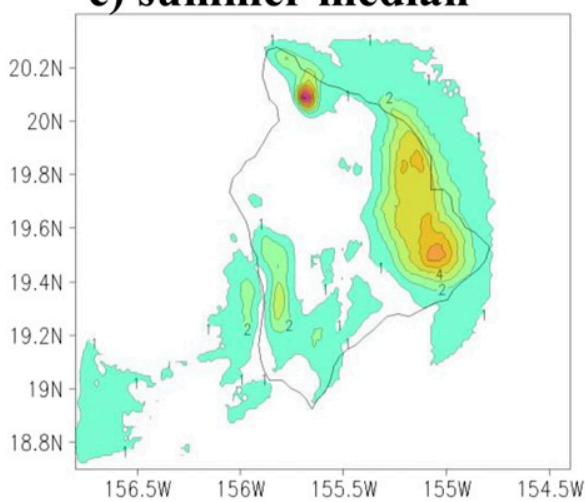

e) STWD median

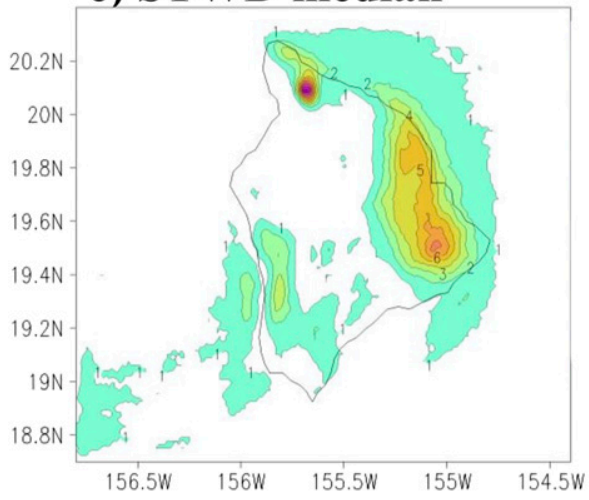

b) winter average

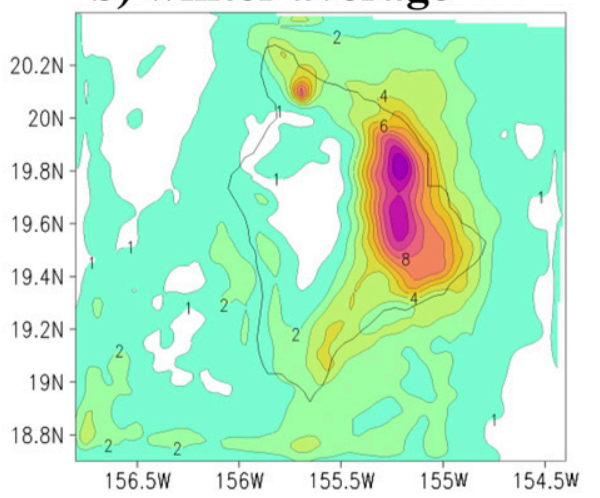

d) winter median

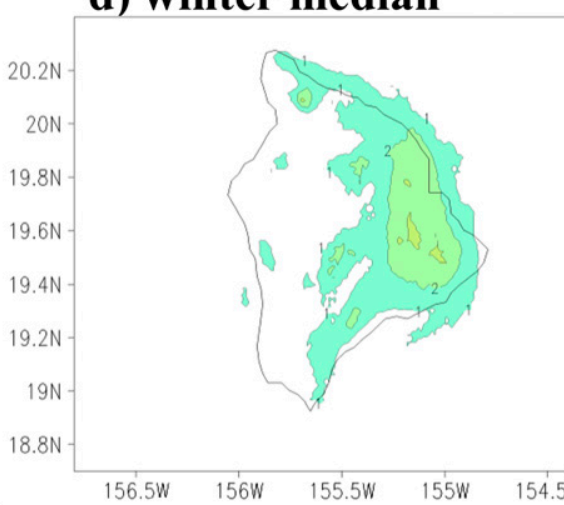

f) WTWD median

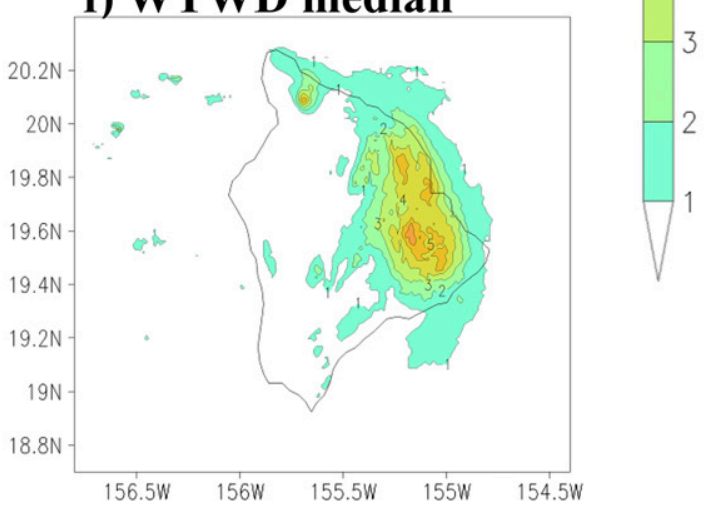

FIG. 2. The simulated daily rainfall (contour every $1 \mathrm{~mm}$ and shading) for (a) the 6-yr summer average, (b) the 6-yr winter average, (c) the 6-yr summer median, (d) the 6-yr winter median, (e) the 6-yr summer median for trade wind days, and (f) the 6-yr winter median for trade wind days.

Chen and Feng 1995). Moreover, the simulated rainfall pattern in the Kona area is consistent with climatological observations (Giambelluca et al. 1986, 2013). In addition, a localized rainfall maximum is simulated off the Kona coast in agreement with Yang et al. (2005; Yang and Chen 2008). During the winter storm season, the simulated daily rainfall accumulation on the windward slopes west of Hilo is higher than that in summer but is much less on the Kona leeside (Figs. 2a,b), which is consistent with the rainfall climatology compiled by Giambelluca et al. (1986, 2013). During the summer months, the median daily rainfall pattern for all days in summer is almost the same as summer trade wind days (STWD) (Figs. 2c,e). This is because during the summer months, trade winds are persistent $\left(6-8 \mathrm{~m} \mathrm{~s}^{-1}\right)$.

There are differences in winter median rainfall between all days in winter and winter trade wind days (WTWD) (Figs. 2d,f). On the windward lower slopes, 
although the simulated mean daily rainfall accumulation in winter (Fig. 2b) is $>3 \mathrm{~mm}$ higher than that in summer (Fig. 2a), the simulated median daily rainfall in winter (Fig. 2d) is lower (Fig. 2c). During this time of the year, without the presence synoptic disturbances, winds over the open ocean are often weak and variable with clear skies over the island except in the afternoon hours (Barnes et al. 2016). By separating out winter trade wind days, we will be able to address the role of local effects on rainfall production under winter trade wind weather.

\section{STWD}

Because the simulated 6-yr median rainfall, circulations, and thermal fields show little differences between summer and STWD because of high trade wind frequency in summer, only results from STWD are presented.

\section{a. Horizontal circulations}

The simulated $10-\mathrm{m}$ winds at 0500 Hawaii standard time (HST) (Fig. 3a) decelerate rapidly from $>6 \mathrm{~m} \mathrm{~s}^{-1}$ upstream to less than $0.5 \mathrm{~m} \mathrm{~s}^{-1}$ with flow splitting offshore due to orographic blocking and nocturnal cooling. Land breezes are simulated on the windward coast as well as in the Kona leeside. The westerly reversed flow $\left(\sim 2.5 \mathrm{~m} \mathrm{~s}^{-1}\right.$ ) between counterrotating vortices (Smith and Grubišić 1993) converges with land breezes over the ocean off the central Kona coast (Fig. 3a).

At 1400 HST (Fig. 3b), the simulated incoming winds decrease rapidly from $>6 \mathrm{~m} \mathrm{~s}^{-1}$ upstream to about $3 \mathrm{~m} \mathrm{~s}^{-1}$ on the windw8ard coast, and merge with the onshore/anabatic winds over the windward slopes. The westerly reversed flow off the Kona coast is slightly stronger than early morning $\left(\sim 3 \mathrm{~m} \mathrm{~s}^{-1}\right)$ and merges with the sea breezes/upslope flow over land.

\section{b. Vertical cross section}

The vertical cross sections describe the three-dimensional thermally driven circulations and vertical profile of the westerly reversed flow adjacent to the Kona coast. For this study, we chose the cross section along $19.4^{\circ} \mathrm{N}$ (Fig. 1b). This cross section is along the axis of the westerly reversed flow between two counterrotating vortices and goes through both the rainfall maxima off the Kona coast and on the Kona slopes.

At $0500 \mathrm{HST}$, the circulations on the leeside of the island along the zonal cross section at $19.4^{\circ} \mathrm{N}$ (Fig. 4a) show that rising motion over the ocean adjoining the Kona coast have a maximum exceeding $>4 \mathrm{~cm} \mathrm{~s}^{-1}$. The rising motion maximum just west of the Kona coast is a result of the low-level convergence between the westerly reversed flow and land breezes (Fig. 4a). Moreover, a maximum in

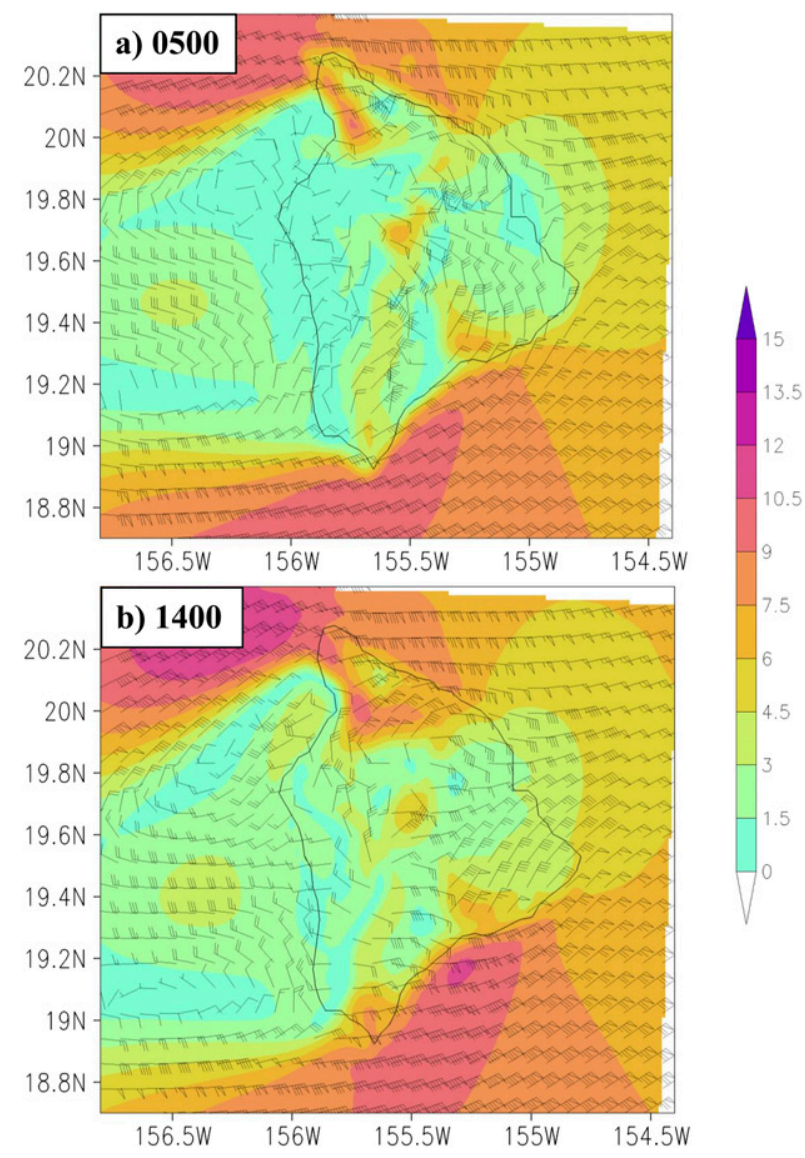

FIG. 3. The simulated diurnal $10-\mathrm{m}$ winds for STWD average (full barb: $1 \mathrm{~m} \mathrm{~s}^{-1}$; pennant: $5 \mathrm{~m} \mathrm{~s}^{-1}$ ) and wind speed $\left(\mathrm{ms}^{-1}\right.$; shading) at (a) 0500 and (b) 1400 HST.

relative humidity ( $>95 \%$ ) occurs there because of rising motions. At 1400 HST (Fig. 4b), the westerly reversed flow merges with the onshore/upslope flow and is lifted on the lower Kona slopes with rising motion $>10 \mathrm{~cm} \mathrm{~s}^{-1}$ and a maximum in relative humidity $(>95 \%)$.

The rising motion off the Kona coast at night, orographic-influenced circulations with upslope winds on the Kona slopes, and the sinking motion over the ocean off west Kona in the afternoon hours are consistent with previous studies (Yang et al. 2005; Yang and Chen 2008).

\section{c. TPW and rainfall}

The simulated total precipitable water (TPW) over the ocean on the windward side is $>34 \mathrm{~mm}$ (Fig. 5) for both 0500 and 1400 HST. The moisture in the leeside wake zone $(>36 \mathrm{~mm})$ is higher than the moisture associated with the incoming large-scale trade wind flow on the windward side $(\sim 34 \mathrm{~mm})$ because of the convergence between two counterrotating vortices in the wake (Fig. 3). In addition, the moisture content of the westerly 

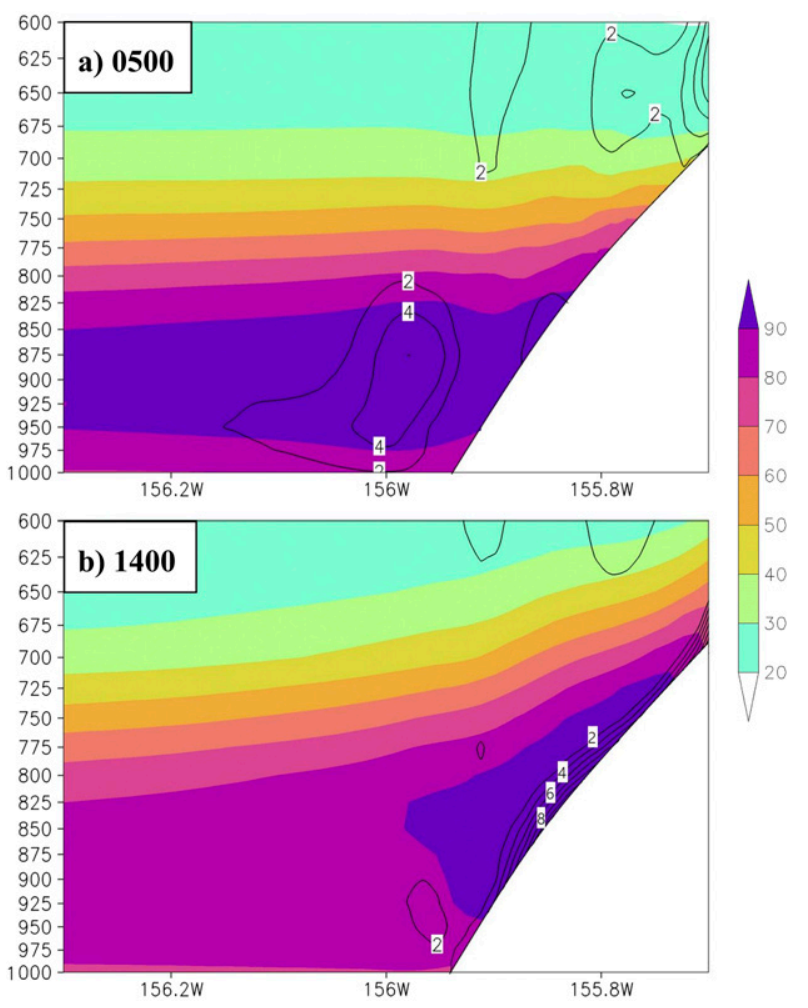

FIG. 4. The simulated diurnal relative humidity ( $\%$; shading) and the vertical motions (contour every $2 \mathrm{~cm} \mathrm{~s}^{-1}$ ) along the cross section $\left(19.4^{\circ} \mathrm{N}\right)$ for STWD average at (a) 0500 and (b) 1400 HST.

reversed flow increases as the flow moves toward the Kona coast and decelerates as a result of orographic blocking. It is striking that the simulated TPW has a local maximum $(>38-40 \mathrm{~mm})$ over the Kona coastal areas (Fig. 5), which is $4-6 \mathrm{~mm}$ higher than the values associated with the large-scale incoming trade wind flow from the open ocean. At 1400 HST, the simulated TPW maximum adjacent to the Kona coast is closer to the island than at early morning as the westerly reversed flow merges with the upslope flow inland. The TPW maximum $(>40 \mathrm{~mm})$ for the decelerating westerly reversed flow is $2 \mathrm{~mm}$ larger than at 0500 HST. A similar increase in the moisture content is also simulated on the windward coast at early morning as the incoming flow decelerates.

There are two Kona trade wind rainfall maxima that occur at different times and areas during the day (Fig. 6). At early morning, the nocturnal rainfall offshore (Fig. 6a) is caused by the convergence between the offshore flow and the moist ( $>38 \mathrm{~mm}$ ) westerly reversed flow (Fig. 5a). The rising motion in response to the low-level convergence between the westerly reversed flow and land breezes results in a rainfall maximum in a relatively moist environment. During 0500-0800 HST, the simulated

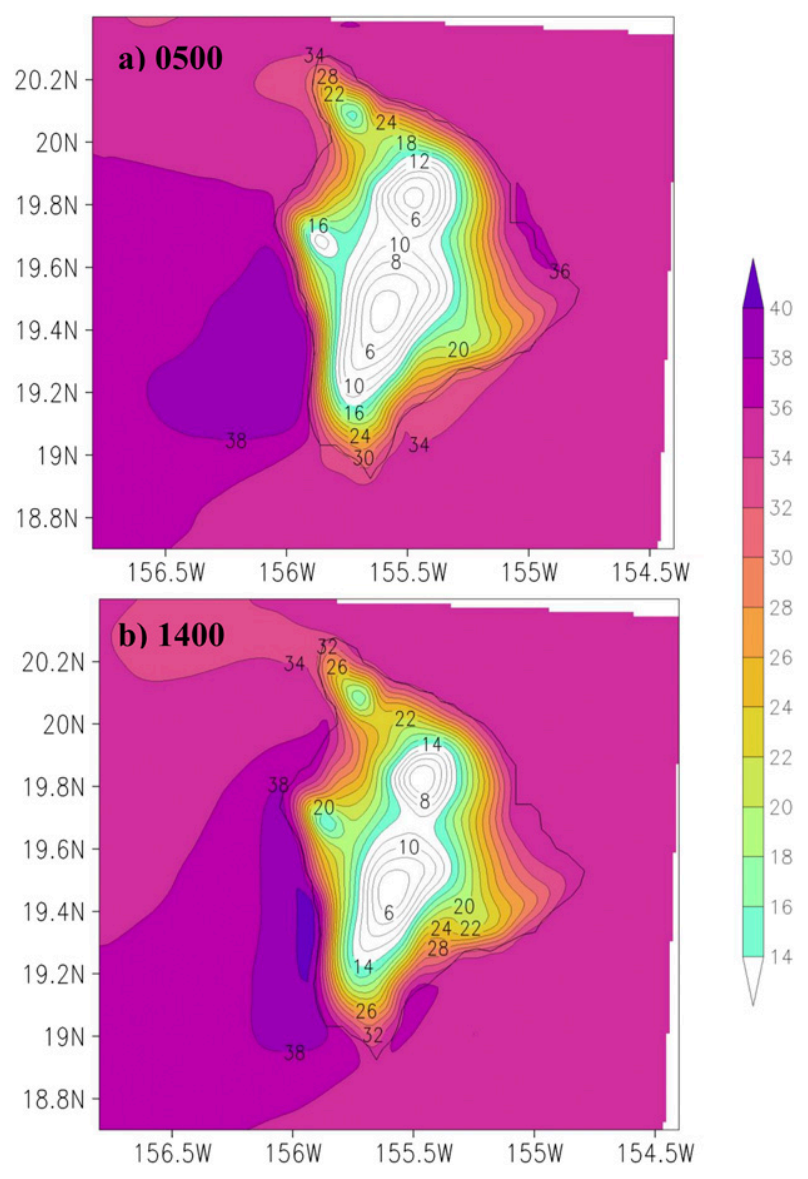

FIG. 5. The simulated diurnal TPW (contour every $2 \mathrm{~mm}$ and shading) for STWD average at (a) 0500 and (b) 1400 HST.

average 3-h rainfall maximum $(\sim 1 \mathrm{~mm})$ occurs adjacent to the Kona coast (Fig. 6a). In the afternoon hours, the warm, moist westerly reversed flow along the Kona coastal area merges with the daytime upslope flow inland bringing in moist air over the Kona slopes. During 1400-1700 HST, the Kona rainfall maximum $(>2.4 \mathrm{~mm})$ occurs on the lower slopes (Fig. 6b) because of orographic lifting of the moist upslope flow.

On the windward side, the early morning (0500-0800 HST), the simulated rainfall has a maximum $(>1.2 \mathrm{~mm})$ along the windward coastal area because of a combination of orographic blocking and nocturnal cooling as the incoming trade wind flow decelerations and converges with the early morning offshore flow (Smolarkiewicz et al. 1988; Takahashi 1977; Chen and Nash 1994) (Fig. 6a). A secondary rainfall maximum $(<0.9 \mathrm{~mm})$ is simulated over the windward coast and lower slopes over the Kohala Mountains in the northern Big Island. In the afternoon (1400-1700 HST) hours, maximum rainfall is simulated over the windward slopes of Mauna Kea, Mauna Kea, and the Kohala Mountains because of 

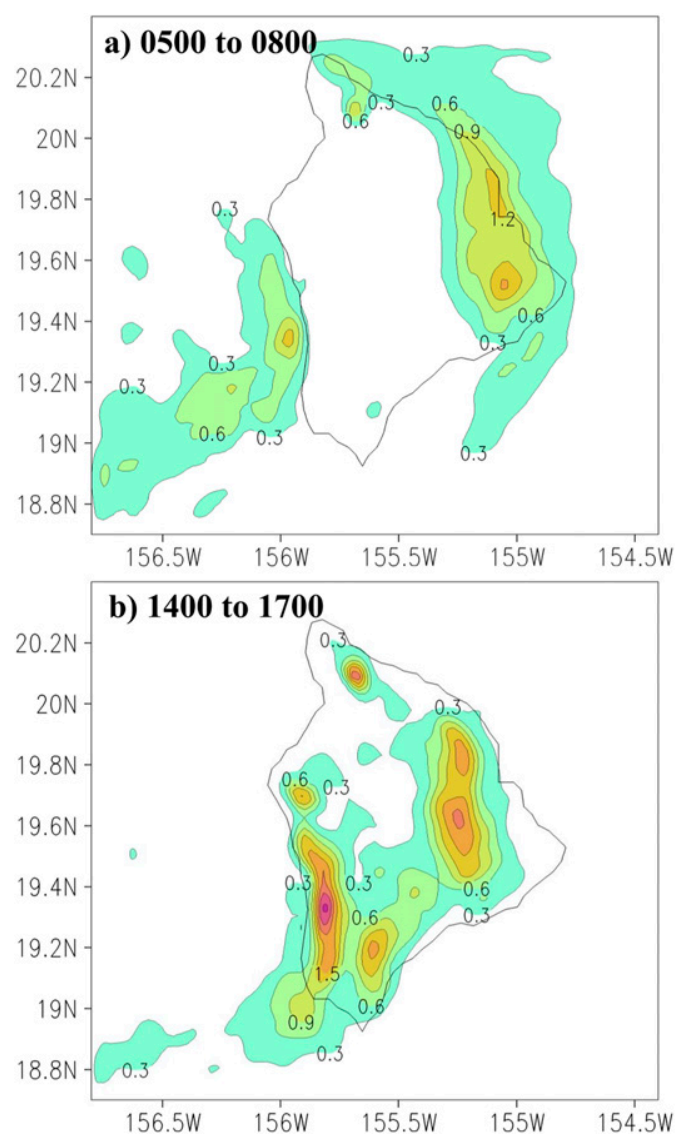

FIG. 6. The simulated 3-h average daily rainfall (contour every $0.3 \mathrm{~mm}$ and shading) for STWD average during (a) 0500-0800 and (b) 1400-1700 HST.

orographic lifting of the combined upslope flow and the incoming decelerating trade wind flow (Chen and Nash 1994). Over the southeastern flank of Mauna Loa, the simulated afternoon rainfall has a maximum over the lower slopes because of the development of the daytime onshore flow. The simulated diurnal rainfall patterns in summer are mainly driven by diurnal and local effects and resemble summer rainfall patterns during HaRP (Chen and Nash 1994; Chen and Feng 1995; Yang et al. 2005; Yang and Chen 2008).

\section{The differences between STWD and WTWD}

During the winter months, there are large day-to-day variations in synoptic patters and only $26.1 \%$ of days are considered as trade wind days in this study. In this section the horizontal and vertical circulations, moisture content, and rainfall for WTWD and STWD are compared. The reasons for more localized Kona leeside rainfall during STWD than in WTWD on the Big Island will be addressed.
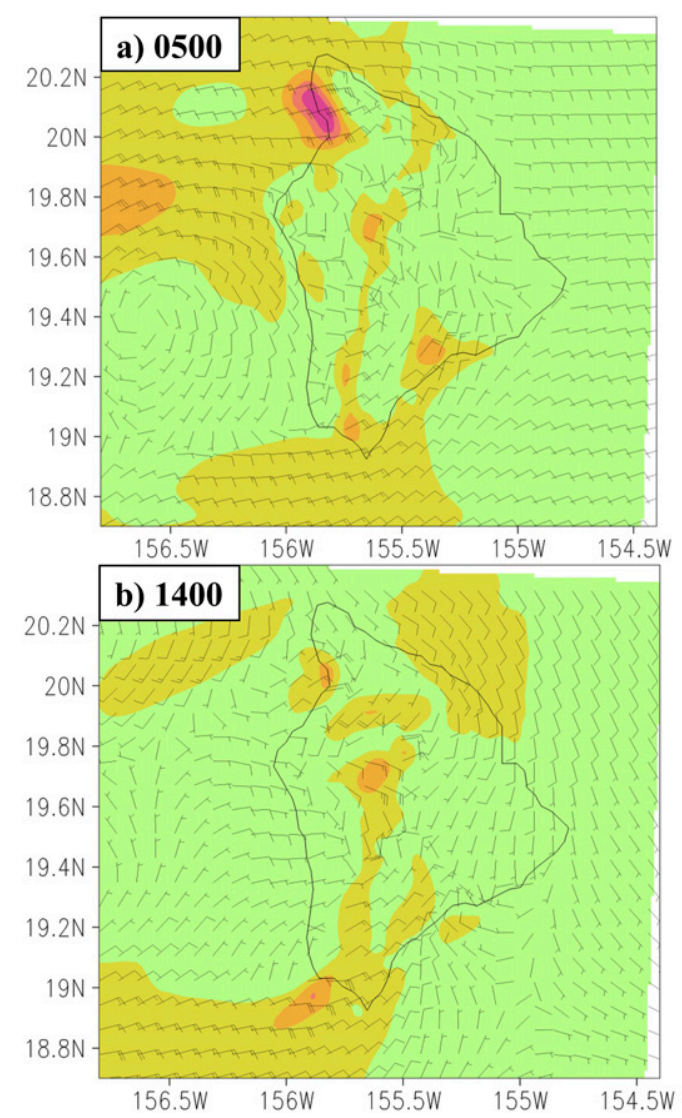

FIG. 7. The differences (WTWD average minus STWD average) in simulated 10-m winds (full barb: $1 \mathrm{~m} \mathrm{~s}^{-1}$; pennant: $5 \mathrm{~m} \mathrm{~s}^{-1}$ ) and in wind speed ( $\mathrm{m} \mathrm{s}^{-1}$; shading) at (a) 0500 and (b) 1400 HST. Note that the differences in wind speed are calculated from the results of wind vector differences.

\section{a. Horizontal circulation}

At $0500 \mathrm{HST}$, the simulated average incoming winds for the WTWD regime are slightly faster $\left(<1 \mathrm{~m} \mathrm{~s}^{-1}\right)$ than STWD (Fig. 7a). In the meantime, the westerly reversed flow off the Kona leeside is slightly weaker with a more southwesterly wind component $\left(\sim 1 \mathrm{~m} \mathrm{~s}^{-1}\right)$ off the Kona coast associated with an anomalous cyclonic circulation in the wake zone. Over the island, the early morning offshore flow is slightly more significant for WTWD than STWD months (Fig. 7a).

At 1400 HST, the simulated 10-m winds on both the Kona leeside slopes and the windward slopes show a stronger onshore/upslope wind component in STWD than WTWD in response to solar heating (Fig. 7b). The westerly reversed flow off the Kona coast in STWD is slightly stronger $\left(\sim 1 \mathrm{~m} \mathrm{~s}^{-1}\right)$ than WTWD.

For STWD, the incoming trade wind flow has higher TPW than in WTWD because of warmer air temperature over the open ocean. For WTWD, the simulated 
mean TPW over the ocean upstream at 0500 HST is more than $3 \mathrm{~mm}$ less than STWD and more than $4 \mathrm{~mm}$ lower in the leeside wake zone (Fig. 8a). The largest differences are more than $6 \mathrm{~mm}$ off the Kona coast, especially in the afternoon hours. At 1400 HST, the simulated mean TPW over the ocean upstream for WTWD is more than $3 \mathrm{~mm}$ less than STWD and more than $4 \mathrm{~mm}$ lower in the leeside wake zone (Fig. 8b). The largest differences ( $>6 \mathrm{~mm}$ ) occur off the Kona coast.

\section{b. Vertical cross section}

At $0500 \mathrm{HST}$, along the zonal cross section at $19.4^{\circ} \mathrm{N}$ (Fig. 1b), the simulated vertical motions off the Kona coast due to the convergence between the offshore flow and the westerly reversed flow in WTWD are $2-3 \mathrm{~cm} \mathrm{~s}^{-1}$ weaker than during STWD (Fig. 9a). This is because the westerly reversed flow off the Kona coast has a lower moisture content for WTWD as compared with STWD. With a lower TPW in WTWD than STWD (Fig. 8a) and smaller moisture convergence, the convective feedback is less significant. The simulated relative humidity for the WTWD is $5 \%-20 \%$ lower than STWD (Fig. 8a), especially at the layer between 850 - and $800-\mathrm{hPa}$ levels, below the typical height of the TWI $(\sim 1.9 \mathrm{~km})$. This is because the easterly return flow aloft associated with the circulation cell over the coast is less pronounced in WTWD than STWD (Fig. 10a). A stronger simulated descending airflow $\left(3 \mathrm{~cm} \mathrm{~s}^{-1}\right)$ in STWD than WTWD is also evident in the upper slopes on the leeside of the saddle between Mauna Kea and Mauna Loa.

At $1400 \mathrm{HST}$, the rising motion on the lower Kona slopes in STWD is about $3-5 \mathrm{~cm} \mathrm{~s}^{-1}$ larger than WTWD (Fig. 9b) because of a weaker westerly reversed flow (Fig. 7b) and less pronounced solar heating on the slopes during the winter months. Furthermore, with a higher TPW associated with the westerly reversed flow that merges with the upslope flow inland (Fig. 8b), the convective feedback to the diurnal driven cell on the Kona slopes is more significant in STWD than WTWD. The anomalous rising motion in STWD extends above the 800-hPa level on the upper Kona slopes (Fig. 9b), which suggests that during the summer months the upslope flow may penetrate the TWI on the upper Kona slopes. The simulated relative humidity on the Kona slopes during STWD is larger than in WTWD and extends upward to the upper slopes (Fig. 10b). Furthermore, during STWD, with a more significant easterly return flow aloft (Fig. 10b) associated with the circulation cell on the slopes than in WTWD, the relatively humidity is much higher $(>30 \%)$ for the layer between the 850 - and 750-hPa levels (Fig. 9b). On the upper slopes, descending
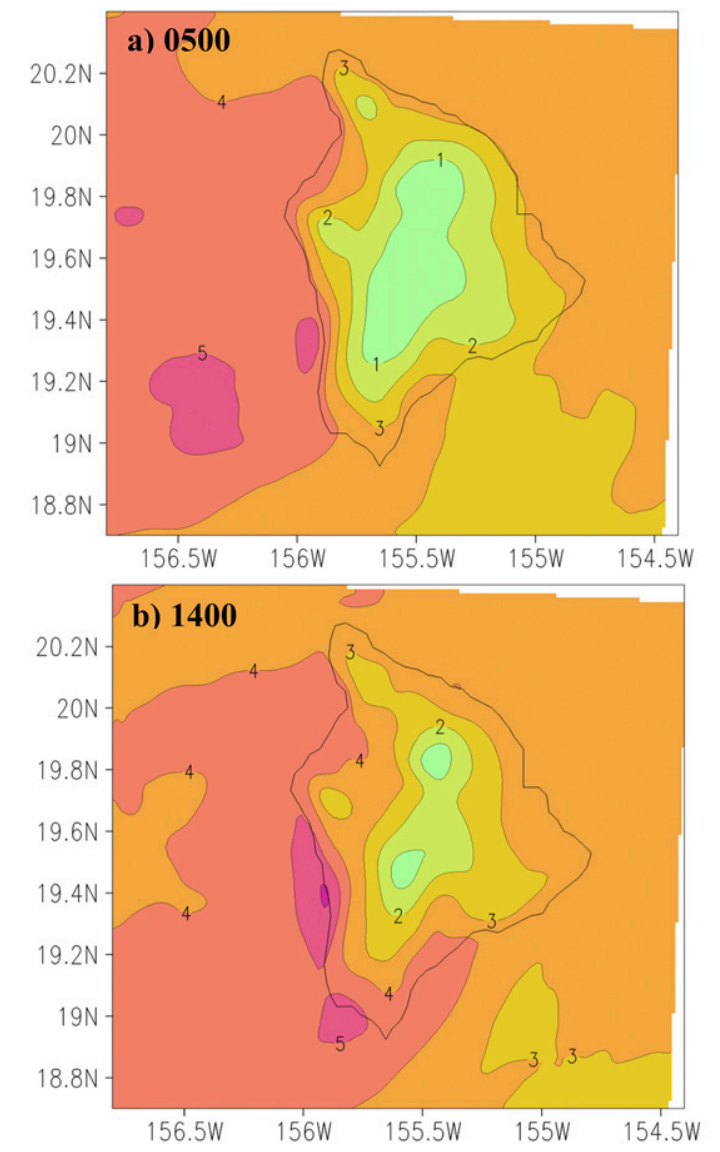

FIG. 8. The differences (STWD average minus WTWD average) in simulated TPW (contour every $1 \mathrm{~mm}$ and shading) at (a) 0500 and (b) 1400 HST.

airflow from the saddle between Mauna Loa and Mauna Kea is more significant in STWD than WTWD (Fig. 9b). Furthermore, the anomalous sinking motions in the upper slopes in afternoon hours are more pronounced than in the early morning as the upslope flow on the windward side moves over the Waimea Saddle and descends in the leeside.

\section{c. Diurnal rainfall}

The average 3-h daily rainfall adjacent to the Kona coast from 0500 to 0800 HST in STWD $(>1.2 \mathrm{~mm})$ (Fig. 6a) is larger than in WTWD $(>0.6 \mathrm{~mm})$ (Fig. 11a) because of a wetter $(\sim 5 \mathrm{~mm})$ (Fig. $8 \mathrm{a}$ ) westerly reversed flow converging with the land breezes in WTWD. In the afternoon, the average 3-h (1400-1700 HST) daily Kona rainfall on the lower slopes in WTWD is only $>0.3 \mathrm{~mm}$ (Fig. 11b) which is much less than $>2.4 \mathrm{~mm}$ in STWD (Fig. 11b). This is caused by stronger orographic lifting of the combined westerly reversed flow and the daytime upslope flow with higher $(\sim 6 \mathrm{~mm}) \mathrm{TPW}$ in STWD than in WTWD (Fig. 8b). 

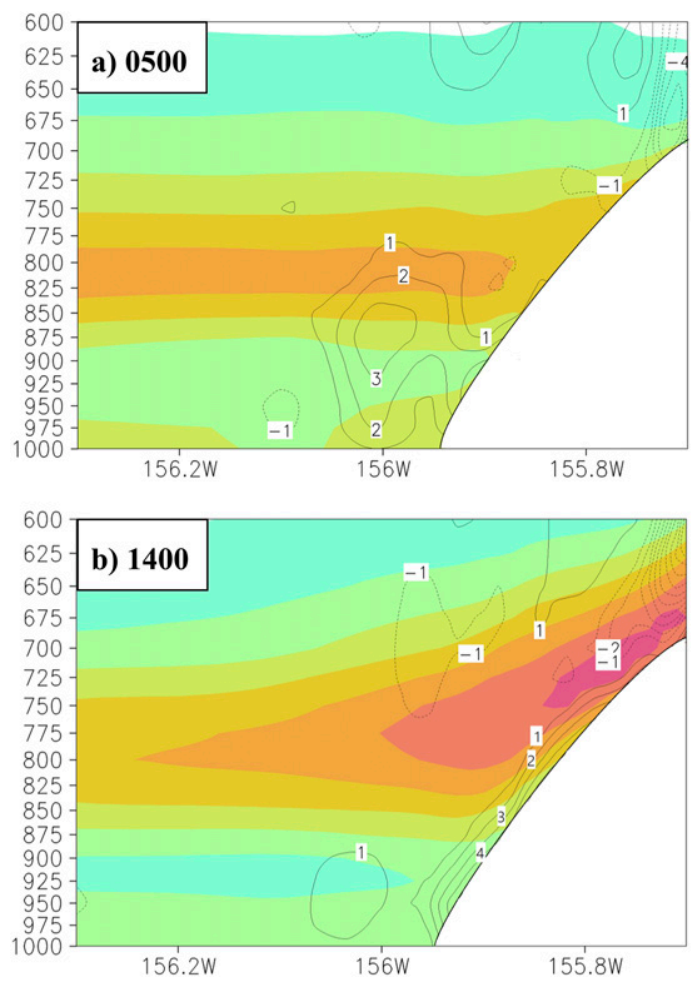

FIG. 9. The differences (STWD average minus WTWD average) in simulated diurnal relative humidity ( $\%$; shading) and the vertical motions (contour every $1 \mathrm{~cm} \mathrm{~s}^{-1}$ ) along the cross section $\left(19.4^{\circ} \mathrm{N}\right)$ at (a) 0500 and (b) 1400 HST.

The considerably higher Kona rainfall for STWD than WTWD under the similar westerly reversed flow indicates that the moisture content in the atmosphere is an important factor for the rainfall production in the Kona area. The higher summer trade wind rainfall over the lower Kona slopes than in WTWD in the afternoon hours is caused by a relatively moist westerly reversed flow transporting moisture inland (Fig. 8b) and merges with a stronger upslope flow (Fig. 7b) under more pronounced solar heating.

On the windward side, under summer trade wind conditions, rainfall diminishes on the windward slopes at early morning (Fig. 6a) because of the development of katabatic flow (Chen and Nash 1994; Feng and Chen 1998). In contrast, considerable early morning rainfall $(>2 \mathrm{~mm})$ is simulated on the windward slopes of Mauna Loa and Mauna Kea in WTWD (Fig. 11a). Relatively large rainfall $(>2 \mathrm{~mm})$ is also simulated in the afternoon hours in WTWD (Fig. 11b). It appears that simulated large rainfall on the windward slopes throughout the diurnal cycle may occur under strong trade wind conditions $\left(>8 \mathrm{~m} \mathrm{~s}^{-1}\right)$ associated with large-scale disturbances (Zhang et al. 2005b). The early morning coastal rainfall due to a combination of orographic blocking and
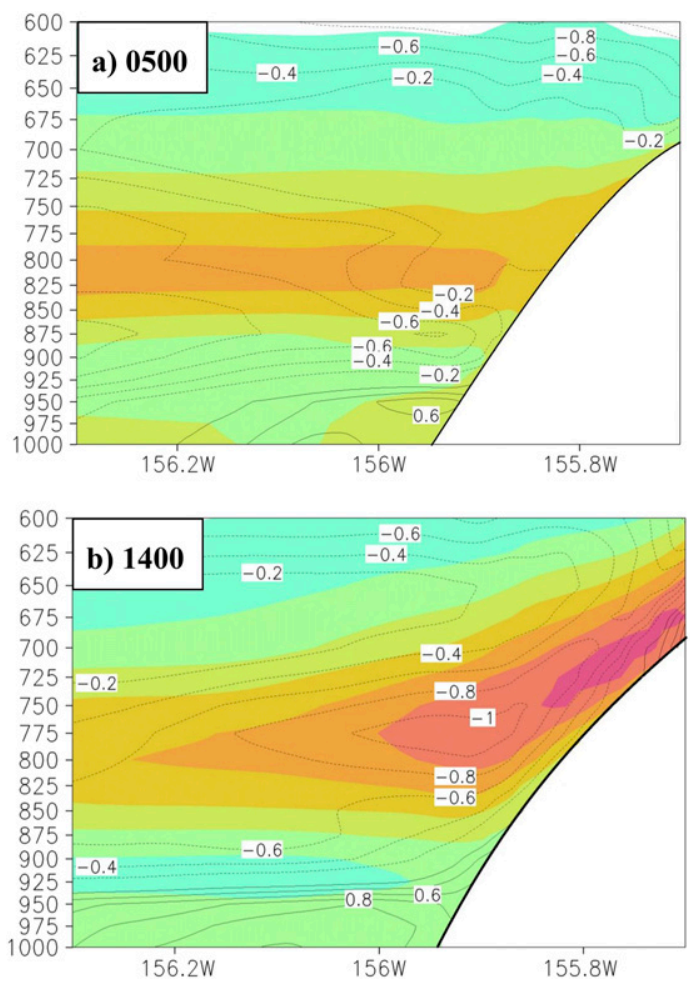

FIG. 10. The differences (STWD average minus WTWD average) in simulated diurnal relative humidity (\%; shading) and the $u$-direction wind (contour every $0.2 \mathrm{~m} \mathrm{~s}^{-1}$ ) along the cross section $\left(19.4^{\circ} \mathrm{N}\right)$ at (a) 0500 and (b) $1400 \mathrm{HST}$.

nocturnal cooling is lower in WTWD than STWD (Figs. 6a and 11a) because of lower TPW. The afternoon rainfall on the windward side of the Kohala Mountains, which is enhanced by the development of upslope flow, is also lower in WTWD than STWD (Figs. 6b and 11b).

\section{The winter average for all days}

The 2-m temperature between WTWD and the 6-yr winter average shows little difference (not shown). The simulated mean TPW over the ocean upstream under WTWD is about $1 \mathrm{~mm}$ less than the winter average (Fig. 12). Moreover, the simulated daily average TPW on the Kona leeside under WTWD is about 0.5 to $1 \mathrm{~mm}$ less than the winter average (Fig. 12). For WTWD, the incoming trade winds at both 0500 HST and 1400 HST are more than $2 \mathrm{~m} \mathrm{~s}^{-1}$ faster than the winter average, and the wind speeds at northern and southern tips are much faster $\left(>4 \mathrm{~m} \mathrm{~s}^{-1}\right)$ than the winter average (Fig. 13). On the Kona leeside, the westerly reversed flow maximum at $0500 \mathrm{HST}$ is $2 \mathrm{~m} \mathrm{~s}^{-1}$ larger than the winter average for all days (Fig. 13a). At 1400 HST, the westerly reversed flow maximum is $1.5 \mathrm{~m} \mathrm{~s}^{-1}$ larger than the winter average for all days (Fig. 13b). 
a) 0200 to $0500 \mathrm{HST}$

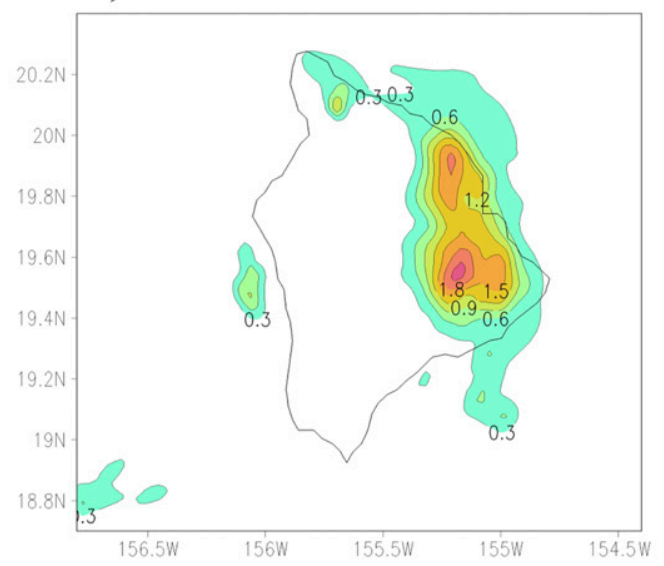

b) 1400 to $1700 \mathrm{HST}$

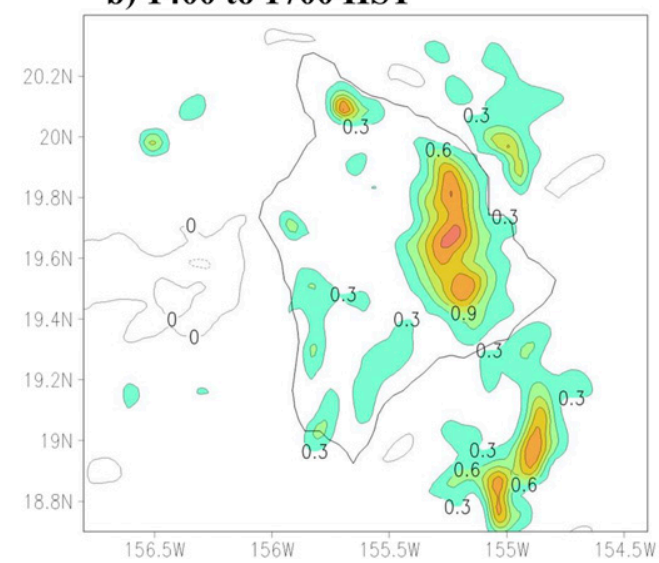

FIG. 11. The Simulated 3-h averaged daily rainfall (contour every $0.3 \mathrm{~mm}$ and shading) for WTWD average during (a) 0500-0800 and (b) 1400-1700 HST.

On the windward side, median daily rainfall is $>3 \mathrm{~mm}$ higher under WTWD as compared to daily median rainfall for all days in winter (Figs. 2d,f). It appears that larger orographic lifting under the WTWD regime results in higher daily median rainfall on the windward side. Under trade wind conditions in winter, there are large day-to-day variations in incoming trade wind speed. In winter, the Hawaiian island chain is frequently suppressed with clear skies and low wind speed as the subtropical ridge is close to the island chain (Barnes et al. 2016). Thus, although the average daily rainfall accumulation for winter months is as large as $12 \mathrm{~mm}$ (Fig. 2b), the simulated median daily rainfall for winter is only $2 \mathrm{~mm}$ (Fig. 2d). A considerable amount of rainfall on the windward slopes west of Hilo during the winter months occurs under disturbed synoptic conditions with strong $\left(>8 \mathrm{~m} \mathrm{~s}^{-1}\right)$ incoming trade winds.

In the Kona area, daily rainfall accumulation off the Kona coast and on the Kona lower slopes is $>2 \mathrm{~mm}$ for all days in winter (Fig. 2b), which is much lower

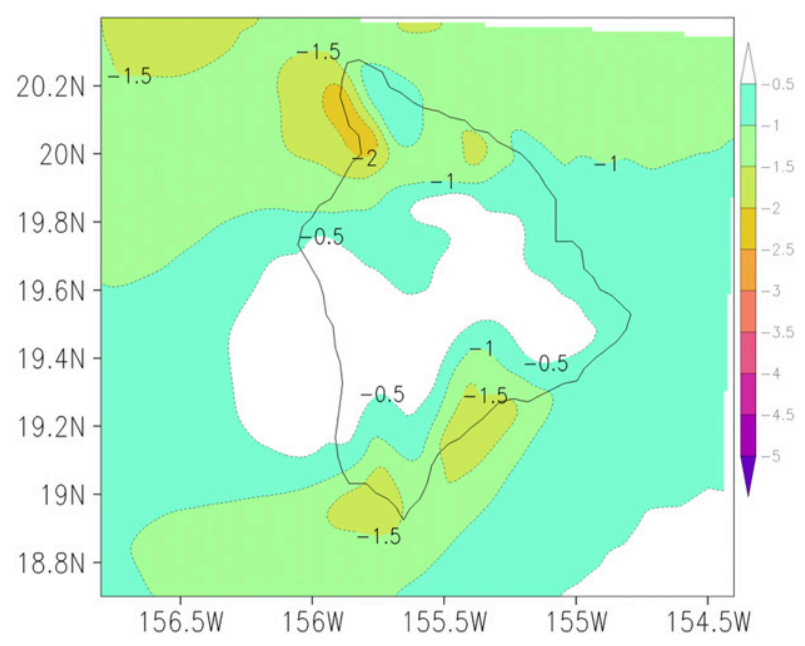

FIG. 12. The simulated daily TPW differences (contour every $0.5 \mathrm{~mm}$ and shading) for WTWD average minus the 6-yr winter average.

than $>6 \mathrm{~mm}$ in STWD (Fig. 2a). This is because the moisture content for the westerly reversed flow is drier in winter than in summer (Fig. 8). Nevertheless, there is very little difference in median winter rainfall between WTWD and all days in winter (Figs. 2d,f), which suggests that the rainfall in the Kona area is mainly caused by local effects.

\section{Summary}

For most stations in the Hawaiian island chain that are well exposed to trade winds, the rainfall climatology in most cases exhibits summer dry, winter wet patterns. The wet winter is related to the passages of winter storms. For the island of Hawaii, the mountaintops of Mauna Kea and Mauna Loa $(>4000 \mathrm{~m})$ are well above the TWI. Trade winds are absent in the Kona leeside area behind the massive volcanoes. The Kona leeside area exhibits summer rainfall maxima. In this study, the seasonal variations in rainfall over the island of Hawaii are studied using the archives of the daily model run from MM5 coupled with the advanced Noah LSM from June 2004 to February 2010.

Our results show that local and orographic effects dominate the Kona leeside rainfall during both the summer and winter seasons. In the leeside of the wake zone, the moisture has a maximum along the axis of westerly reversed flow because of the convergent airflow between two counterrotating vortices. As the moist westerly reversed flow moves toward the coast, it decelerates with increasing moisture with a maximum over the Kona coast.

During the winter months, only $<27 \%$ of the days are classified as trade wind days (WTWD). For WTWD, the 

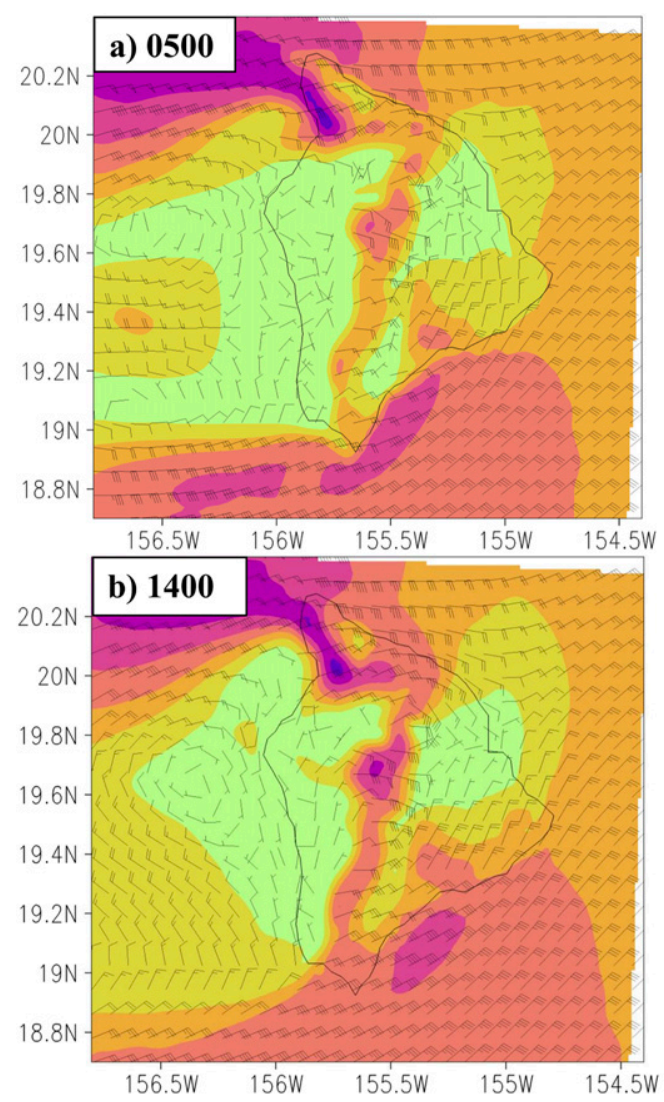

FIG. 13. The differences (WTWD average minus 6-yr winter average) in simulated $10-\mathrm{m}$ winds (full barb: $1 \mathrm{~m} \mathrm{~s}^{-1}$; pennant: $\left.5 \mathrm{~m} \mathrm{~s}^{-1}\right)$ and in wind speed $\left(\mathrm{m} \mathrm{s}^{-1}\right.$; shading) at (a) 0500 and (b) 1400 HST. Note that the differences in wind speed are calculated from the results of wind vector differences.

average speed of the incoming trade winds is slightly higher than the STWD with a slightly faster westerly reversed flow between two counterrotating vortices in the wake zone. However, over the open ocean with a warmer temperature, the moisture content for the incoming trade wind flow for STWD is more than $3 \mathrm{~mm}$ higher than WTWD. In the wake zone, the moisture is more than $4 \mathrm{~mm}$ higher in STWD than in WTWD. The largest differences occur in the Kona coast area $(>6 \mathrm{~mm})$, especially in the afternoon hours. In STWD, the higher trade wind rainfall in the Kona slopes in the afternoon hours is mainly because the moist westerly reversed flow transporting moisture inland and merges with the stronger upslope flow because of more pronounced solar heating. Higher nocturnal rainfall offshore in STWD is a result of low-level convergence between a moister westerly reversed flow with the offshore flow.

On the windward side, the simulated daily rainfall accumulation over the windward lowlands west of Hilo during the winter months is higher than summer months because of the frequently observed strong trade winds associated with winter storms. The higher rainfall on the windward side in winter is due to a combination of synoptic processes enhanced by orographic effects. Nevertheless, early morning trade wind rainfall along the windward coast and afternoon rainfall over the windward slopes of the Kohala Mountains is lower in winter because the incoming trades are drier.

Acknowledgments. This work is funded by the National Science Foundation under Grant AGS-1142558 to the University of Hawai'i at Manoa. The real-time experimental MM5 data were generated by H. N. Nguyen with funding support from the U.S. Forest Service under Agreement 05-JV-11272165-015. Addition reruns of MM5 for missing days were made by H. N. Nguyen and K. Chua with funding support from the U.S. Army Corps of Engineers and the State of Hawaii (principal investigator: T. Giambelluca). The authors thank Gary Barnes for his comments and May Izumi for editing the text.

\section{REFERENCES}

Austin, G. R., R. M. Rauber, H. T. Ochs III, and L. J. Miller, 1996: Trade-wind clouds and Hawaiian rainbands. Mon. Wea. Rev., 124, 2126-2151, https://doi.org/10.1175/15200493(1996)124<2126:TWCAHR > 2.0.CO;2.

Barnes, M. L., T. Miura, and T. W. Giambelluca, 2016: An assessment of diurnal, and seasonal cloud cover changes over the Hawaiian island using terra and Aqua MODIS. J. Climate, 29, 77-90, https://doi.org/10.1175/JCLI-D-15-0088.1.

Blumenstock, D. I., and S. Price, 1967: Climate of Hawaii. Climates of the States 60-51, Climatography of the United States, U.S. Department of Commerce, 27 pp.

Carbone, R. E., W. A. Cooper, and W. C. Lee, 1995: Forcing of flow reversal along the windward slopes of Hawaii. Mon. Wea. Rev., 123, 3466-3480, https://doi.org/10.1175/1520-0493(1995) $123<3466$ :FOFRAT $>2.0$. CO 2 .

— J. D. Tuttle, W. A. Cooper, V. Grubišić, and W. C. Lee, 1998: Trade wind rainfall near the windward coast of Hawaii. Mon. Wea. Rev., 126, 2847-2863, https://doi.org/10.1175/ 1520-0493(1998)126<2847:TWRNTW>2.0.CO;2.

Carlis, D. L., Y.-L. Chen, and V. Morris, 2010: Numerical simulations of island-scale airflow and the Maui vortex during summer trade wind conditions. Mon. Wea. Rev., 138, 2706-2736, https://doi.org/10.1175/2009MWR3236.1.

Chen, F., and J. Dudhia, 2001: Coupling an advanced land surfacehydrology model with the Penn State-NCAR MM5 Modeling System. Part I: Model implementation and sensitivity. Mon. Wea. Rev., 129, 569-585, https://doi.org/10.1175/1520-0493(2001) $129<0569$ :CAALSH $>2.0 . \mathrm{CO} ; 2$.

Chen, Y.-L., and A. J. Nash, 1994: Diurnal variation of surface airflow and rainfall frequencies on the island of Hawaii. Mon. Wea. Rev., 122, 34-56, https://doi.org/10.1175/1520-0493(1994) $122<0034$ :DVOSAA $>2.0$. CO; 2 .

_ precipitation and airflow over the island of Hawaii. Mon. Wea. Rev., 123, 1660-1676, https://doi.org/10.1175/1520-0493(1995) $123<1660$ :TIOIHO $>2.0$.CO; 2 . 
— and -2001 : Numerical simulations of airflow and cloud distributions over the windward side of the island of Hawaii. Part I: The effects of trade wind inversion. Mon. Wea. Rev., 129, 1117-1134, https://doi.org/10.1175/1520-0493(2001) 129<1117:NSOAAC $>2.0 . C O ; 2$.

Cram, R. S., and H. R. Tatum, 1979: Record torrential rainstorms on the island of Hawaii, January-February 1979. Mon. Wea. Rev., 107, 1653-1662, https://doi.org/10.1175/1520-0493(1979) 107<1653:RTROTI >2.0.CO;2.

Dudhia, J., 1989: Numerical study of convection observed during the Winter Monsoon Experiment using a mesoscale two-dimensional model. J. Atmos. Sci., 46, 3077-3107, https://doi.org/10.1175/15200469(1989)046<3077:NSOCOD>2.0.CO;2.

Ek, M. B., K. E. Mitchell, Y. Lin, E. Rogers, P. Grunmann, V. Koren, G. Gayno, and J. D. Tarpley, 2003: Implementation of Noah land surface model advances in the National Centers for Environmental Prediction operational mesoscale Eta Model. J. Geophys. Res., 108, 8851, https://doi.org/10.1029/ 2002JD003296.

Esteban, M. A., and Y.-L. Chen, 2008: The impact of trade wind strength on precipitation over the windward side of the island of Hawaii. Mon. Wea. Rev., 136, 913-928, https://doi.org/ 10.1175/2007MWR2059.1.

Feng, J., and Y.-L. Chen, 1998: Evolution of katabatic winds on the island of Hawaii during 10 August 1990. Mon. Wea. Rev., 126, 2185-2199, https://doi.org/10.1175/1520-0493(1998)126<2185: EOKFOT $>2.0 . \mathrm{CO} ; 2$.

— cloud distributions over the windward side of the island of Hawaii. Part II: Nocturnal flow regime. Mon. Wea. Rev., 129, 1135-1147, https://doi.org/10.1175/1520-0493(2001)129<1135: NSOAAC $>2.0 . \mathrm{CO} ; 2$.

Frye, J., and Y.-L. Chen, 2001: Evolution of downslope flow under strong opposing trade winds and frequent trade wind rainshowers over the island of Hawaii. Mon. Wea. Rev., 129, 956-977, https:// doi.org/10.1175/1520-0493(2001)129<0956:EODFUS>2.0.CO;2.

Garrett, A. J., 1980: Orographic cloud over the eastern slopes of Mauna Loa Volcano, Hawaii, related to insolation and wind. Mon. Wea. Rev., 108, 931-941, https://doi.org/10.1175/15200493(1980)108<0931:OCOTES>2.0.CO;2.

Giambelluca, T. W., and T. A. Schroeder, 1998: Climate. Atlas of Hawaii, 3rd ed. S. P. Juvik and J. O. Juvik, Eds., University of Hawai'i Press, 49-59.

- M. A. Nullet, and T. A. Schroeder, 1986: Rainfall atlas of Hawaii. Dept. of Land and Natural Resources Rep. R76, 267 pp.

-, Q. Chen, A. G. Frazier, J. P. Price, Y.-L. Chen, P.-S. Chu, J. K. Eischeid, and D. M. Delparte, 2013: Online rainfall atlas of Hawai'i. Bull. Amer. Meteor. Soc., 94, 313-316, https:// doi.org/10.1175/BAMS-D-11-00228.1.

Grell, G. A., 1993: Prognostic evaluation of assumptions used by cumulus parameterizations. Mon. Wea. Rev., 121, 764-787, https:// doi.org/10.1175/1520-0493(1993)121<0764:PEOAUB > 2.0.CO;2.

Hartley, T. M., and Y. Chen, 2010: Characteristics of summer trade wind rainfall over Oahu. Wea. Forecasting, 25, 1797-1815, https://doi.org/10.1175/2010WAF2222328.1.

Hong, S.-Y., and H. L. Pan, 1996: Nonlocal boundary layer vertical diffusion in a medium-range forecast model. Mon. Wea. Rev., 124, 2322-2339, https://doi.org/10.1175/1520-0493(1996)124<2322: NBLVDI>2.0.CO;2.

Hsie, E.-Y., R. A. Anthes, and D. Keyser, 1984: Numerical simulation of frontogenesis in a moist atmosphere. J. Atmos. Sci., 41, 2581-2594, https://doi.org/10.1175/1520-0469(1984) $041<2581$ :NSOFIA $>2.0$. CO 2 .
Jayawardena, I. M. S., Y.-L. Chen, A. J. Nash, and K. Kodama, 2012: A comparison of three prolonged periods of heavy rainfall over the Hawaiian Islands. J. Appl. Meteor. Climatol., 51, 722-744, https://doi.org/10.1175/JAMC-D-11-0133.1.

Jorgensen, D. P., and M. A. LeMone, 1989: Vertical velocity characteristics of oceanic convection. J. Atmos. Sci., 46, 621-640, https://doi.org/10.1175/1520-0469(1989)046<0621: VVCOOC $>2.0 . \mathrm{CO} ; 2$.

Juang, H.-M. H., C.-T. Lee, Y. Zhang, M.-C. Wu, Y.-L. Chen, K. Kodama, and S.-C. Chen, 2005: Applying horizontal diffusion on pressure surface to mesoscale models on terrain-following coordinates. Mon. Wea. Rev., 133, 1384-1402, https://doi.org/10.1175/ MWR2925.1.

Kidd, C., and G. McGregor, 2007: Observation and characterisation of rainfall over Hawaii and surrounding region from the Tropical Rainfall Measuring Mission. Int. J. Climatol., 27, 541-553, https://doi.org/10.1002/joc.1414.

Kodama, K., and G. M. Barnes, 1997: Heavy rain events over the south-facing slopes of Hawaii: Attendant conditions. Wea. Forecasting, 12, 347-367, https://doi.org/10.1175/15200434(1997)012<0347:HREOTS > 2.0.CO;2.

— in the Pacific Region of the National Weather Service. Wea. Forecasting, 13, 523-546, https://doi.org/10.1175/15200434(1998)013<0523:WAFCIT>2.0.CO;2.

Leopold, L. B., 1949: The interaction of trade wind and sea breeze, Hawaii. J. Meteor., 6, 312-320, https://doi.org/10.1175/15200469(1949)006<0312:TIOTWA $>2.0 . \mathrm{CO} ; 2$.

Li, J., and Y.-L. Chen, 1999: A case study of nocturnal showers over the windward coastal region of the island of Hawaii. Mon. Wea. Rev., 127, 2674-2692, https://doi.org/10.1175/15200493(1999) $127<2674:$ ACSONR > 2.0.CO;2.

Meisner, B. N., 1976: A study of Hawaiian and Line Islands rainfall. M.S. thesis, Dept. of Meteorology, University of Hawaii, U.H. Met. 76-04, 142 pp.

Nguyen, H. V., Y.-L. Chen, and F. Fujioka, 2010: Numerical simulations of island effects on airflow and weather during the summer over Oahu. Mon. Wea. Rev., 138, 2253-2280, https:// doi.org/10.1175/2009MWR3203.1.

Nickerson, E. C., and M. A. Dias, 1981: On the existence of atmospheric vortices downwind of Hawaii during the HAMEC project. J. Appl. Meteor., 20, 868-873, https://doi.org/10.1175/ 1520-0450(1981)020<0868:OTEOAV >2.0.CO;2.

Patzert, W. C., 1969: Eddies in Hawaiian waters. University of Hawaii Hawaii Institute of Geophysics Rep. HIG-69-8, $51 \mathrm{pp}$.

Rasmussen, R. M., and P. K. Smolarkiewicz, 1993: On the dynamics of Hawaiian cloud bands. Part III: Local aspects. J. Atmos. Sci., 50, 1560-1572, https://doi.org/10.1175/1520-0469(1993) $050<1560$ :OTDOHC $>2.0 . \mathrm{CO} ; 2$.

Schär, C., and R. B. Smith, 1993: Shallow-water flow past isolated topography. Part II: Transition to vortex shedding. J. Atmos. Sci., 50, 1401-1412, https://doi.org/10.1175/1520-0469(1993) 050<1401:SWFPIT $>2.0$. CO;2.

Schroeder, T., 1981: Characteristics of local winds in northwest Hawaii. J. Appl. Meteor., 20, 874-881, https://doi.org/10.1175/ 1520-0450(1981)020<0874:COLWIN $>2.0$. CO;2. 1993: Climate controls. Prevailing Trade Winds, M. Sanderson, Ed., University of Hawaii Press, 12-36.

B. J. Kilonsky, and B. N. Meisner, 1977: Diurnal variation in rainfall and cloudiness. University of Hawaii Dept. of Meteorology UHMET Rep. 77-03, 67 pp., https://scholarspace.manoa.hawaii.edu/ bitstream/10125/1852/wrrctr112.PDF. 
Smith, R. B., and V. Grubišić, 1993: Aerial observation of Hawaii’s wake. J. Atmos. Sci., 50, 3728-3750, https://doi.org/10.1175/ 1520-0469(1993)050<3728:AOOHW>2.0.CO;2.

Smolarkiewicz, P. K., and R. Rotunno, 1989: Low Froude number flow past three-dimensional obstacles. Part I: Baroclinically generated lee vortices. J. Atmos. Sci., 46, 11541164, https://doi.org/10.1175/1520-0469(1989)046<1154: LFNFPT $>2.0 . \mathrm{CO} ; 2$.

— of Hawaiian cloud bands: Island forcing. J. Atmos. Sci., 45, 1872-1905, https://doi.org/10.1175/1520-0469(1988)045<1872: OTDOHC $>2.0 . \mathrm{CO} ; 2$.

Takahashi, T., 1977: Rainfall at Hilo, Hawaii. J. Meteor. Soc. Japan, 55, 121-129, https://doi.org/10.2151/jmsj1965.55.1_121.

_- 1987: Hawaiian hailstones-30 January 1985. Bull. Amer. Meteor. Soc., 68, 1530-1534, https://doi.org/10.1175/1520-0477(1987) 068<1530:HHJ $>2.0 . \mathrm{CO} ; 2$.

—_, K. Yoneyama, and Y. Tsubota, 1989: Rain duration in Hawaiian trade-wind rainbands-Aircraft observations. J. Atmos. Sci., 46, 937-955, https://doi.org/10.1175/15200469(1989)046<0937:RDIHTW >2.0.CO;2.

Tu, C.-C., and Y.-L. Chen, 2011: Favorable conditions for the development of a heavy rainfall event over Oahu during the 2006 wet period. Wea. Forecasting, 26, 280-300, https://doi.org/ 10.1175/2010WAF2222449.1.

Wang, J.-J., and Y.-L. Chen, 1998: A case study of Hawaiian trade wind rainbands and their interaction with the island-induced airflow. Mon. Wea. Rev., 126, 409-423, https://doi.org/10.1175/ 1520-0493(1998)126<0409:ACSOTW>2.0.CO;2.
Winning, T., Y.-L. Chen, and F. Xie, 2017: Estimation of the marine boundary layer height over the central North Pacific using GPS radio occultation. Atmos. Res., 183, 362-370, https:// doi.org/10.1016/j.atmosres.2016.08.005.

Yang, Y., and Y.-L. Chen, 2003: Circulations and rainfall on the leeside of the island of Hawaii during HaRP. Mon. Wea. Rev., 131, 2525-2542, https://doi.org/10.1175/1520-0493(2003) $131<2525$ :CAROTL $>2.0$. CO 2 .

$\longrightarrow$, and — 2008: Effects of terrain heights and sizes on islandscale circulations and rainfall for the island of Hawaii during HaRP. Mon. Wea. Rev., 136, 120-146, https://doi.org/10.1175/ 2007MWR1984.1.

,-- , and F. M. Fujioka, 2005: Numerical simulations of the island-induced circulation over the island of Hawaii during HaRP. Mon. Wea. Rev., 133, 3693-3713, https://doi.org/ 10.1175/MWR3053.1.

Zhang, Y., Y.-L. Chen, S.-Y. Hong, H.-M. H. Juang, and K. Kodama, 2005a: Validation of the coupled NCEP mesoscale spectral model and an advanced land surface model over the Hawaiian Islands. Part I: Summer trade wind conditions and a heavy rainfall event. Wea. Forecasting, 20, 847-872, https://doi.org/10.1175/WAF891.1.

,-- , and K. Kodama, 2005b: Validation of the coupled NCEP mesoscale spectral model and an advanced land surface model over the Hawaiian Islands. Part II: A high wind event. Wea. Forecasting, 20, 873-895, https://doi.org/10.1175/WAF892.1.

, T. A. Schroeder, and K. Kodama, 2005c: Numerical simulations of sea breeze circulations over northwest Hawaii. Wea. Forecasting, 20, 827-846, https://doi.org/10.1175/WAF859.1. 